\title{
Article
}

\section{Thyroid Follicles and Parenchyma are Found to Increase with Advancing age during the first 50 years of life in Bangladeshi People}

\author{
Nurunnabi ASM ${ }^{1}$, Mahbub S ${ }^{2}$, Shahriah ${ }^{3}$, Begum GN ${ }^{4}$, Ara ${ }^{5}$
}

\begin{abstract}
Background: The structural components of the thyroid gland are very much responsive to many types of stimuli and their adaptation is evident in histological studies. The thyroid follicles change their size and shape with the physiological alterations and pathological deviations. Objective: To observe the histological changes of the thyroid gland with advancing age in Bangladeshi people. Methods: This cross-sectional study was carried out in the Department of Anatomy, Dhaka Medical College, Dhaka from January to December 2008. The present study was performed on 60 post mortem human thyroid gland (39 of male and 21 of female) collected from unclaimed dead bodies which were in the morgue under examination in the Department of Forensic Medicine, Dhaka Medical College, Dhaka. The samples were divided into three age-groups including Group A (10 - 20 years), Group B ( 21 - 50 years) \& Group C (> 50 years) and the glands were studied histologically including number and average diameter of the thyroid follicles, percentage proportion of the parenchyma and stroma. Results and conclusion: All the histological values of the thyroid gland studied i.e. number and average diameter of the thyroid follicles and percentage of the parenchyma, are found to increase with advancing age during the first 50 years of life and later decrease.
\end{abstract}

Key Words: Thyroid gland, Thyroid follicles, Parenchyma, Stroma

J Bangladesh Soc Physiol. 2009 Dec;4(2): 88-92

For author affiliations, see end of text.

http//www.banglajol.info/index.php/JBSP

\section{Introduction}

$\mathbf{S}$ ecretory follicles constitute the functional and structural units of the thyroid gland ${ }^{1}$. The follicles which consist of spheres formed by simple epithelium having a lumen filled with gelatinous substance called colloid ${ }^{2}$. About 30 millions of follicles are packed together to form the human thyroid gland. The structural components of the thyroid gland respond to many types of stimuli and are in a state of regular adaptation i.e. size and shape of the follicles; their content and height of the epithelium vary with the functional condition of the gland ${ }^{1}$. Histometric measurements of the gland can define the structural adaptations to physiological changes, or disease more precisely ${ }^{3}$. Any physiological change or stress is reflected in transient hyperplasia of the thyroid epithelium and reversibly involution occurs and follicular cells resume their normal size, when stress abates. Failure of this normal balance between hyperplasia and involution may produce major or minor deviation from usual histologic pattern including various types of neoplasia ${ }^{4}$. So the histologic study of the thyroid gland is very important. The thyroid gland is an ideal organ for morphometric study due to its compact form

J Bangladesh Soc Physiol. 2009 Dec;4(2): 88-92 


\section{Article}

and uniform distribution of tissue components ${ }^{5}$. The present study was a modest effort to see the histometric alterations in different age group and thereby correlate the functional change of the thyroid gland with advancing age.

\section{Methods}

A cross-sectional descriptive type of study was designed and done in the Department of Anatomy, Dhaka Medical College, Dhaka from January to December 2008, based on collection of 60 human thyroid glands from the unclaimed dead bodies that were under examination in the Department of Forensic Medicine, Dhaka Medical College, Dhaka from February to October 2008. All the samples were collected within 24-36 hours of death without any sign of putrefaction. All the samples were collected from medico legal cases excluding hanging, poisoning, any cutting or crushing injury to the thyroid gland and known case of thyroid disease. This research work was approved by the Ethical Review Committee of Dhaka Medical College, Dhaka.

This research work was approved by the Ethical Review Committee of Dhaka Medical College, Dhaka.

Grouping of the samples: The samples were divided into three age-groups i.e. Group A (10 20 years), Group B (21-50 years) \& Group C ( $>50$ years) according to Brown, Al-Moussa and Beck $(1986)^{3}$.

Table I: Grouping of the sample $(n=60)$

\begin{tabular}{lccc}
\hline Group & Age limit in & \multicolumn{2}{c}{ Number of samples } \\
& years & Male & Female \\
\hline A & $10-20$ years & 08 & 05 \\
B & $21-50$ years & 24 & 10 \\
C & $>50$ years & 07 & 06 \\
\hline
\end{tabular}

Preparation of the slide: Tissue blocks were fixed in $10 \%$ formol saline in a plastic container. The
Thyroid Follicles and Parenchyma in Bangladeshi People

tissues were washed in running tap water, dehydration was done with ascending grades of alcohol, cleared with xylene, infiltrated and embedded in paraffin. Paraffin blocks were cut at $5 \mathrm{~mm}$ thickness and were stained with routine Harris' Haematoxylin and Eosin (H \& E) stain.

Microscopic measurement: The light compound microscope which was used for the microscopic measurement was OLYMPUS CHB, made in Tokyo, Japan. All the variables were studied under low power objective (' 10 objective, ' 10 eyepiece). From each age group 10 best prepared slides were taken.

i) Estimation of number of the thyroid follicles per square mm: According to Enayetullah (1996) ${ }^{6}$, the stained tissue section on the slide was divided into three equal parts by a computer generated, photographically produced equal sized room over a transparent plastic sheet by drawing three lines which radiated from the centre towards the periphery at 10 o'clock, 2 o'clock and 6 o'clock position. Then, this sheet was fixed on the top of the cover slip by an adhesive tape. The centre of this sheet corresponded with the centre of the tissue section. From each triangular area, one microscopic field was selected near the centre for study. Thus from each slide, three different fields were chosen for counting the number of follicles. Therefore, from each group 30 fields were taken for the study. The counting was done within a counting circle specially devised for this purpose. A counting circle of 5 $\mathrm{mm}$ diameter was printed on a transparent plastic sheet, which was cut to fit into the eyepiece of the light microscope. Thus a black circular outline was superimposed over the actual microscopic field. The circle encircled some total of the thyroid follicles, while some other follicles were partly included inside that circle. However, the rest of the follicles were also seen. Considering this circle as the field to be studied (rather than the whole microscopic field), the portions of the follicles inside this field were taken in consideration by an eye estimate e.g. $1,0.75,0.5$,

J Bangladesh Soc Physiol. 2009 Dec;4(2): 88-92 
0.25 etc. From the three counts of three different fields of each slide, an average count was calculated for each slide. Thus the average counts of 10 slides for each group were available. The count was then converted into number per square mm by conversion measurement of an ocular micrometer and a stage micrometer ${ }^{6}$.

ii) Measurement of diameter of the thyroid follicles: For measurement of the diameter of the thyroid follicles, three different fields were chosen from each slide and from each field 5 follicles of different size were observed. The diameter of follicles was measured by using a stage micrometer and ocular micrometer. Two measurements were taken for each follicle. One measurement was taken at the maximum transverse diameter of follicle and another at perpendicular to the first one ${ }^{6}$. So the average diameter of the thyroid follicle was measured by taking the mean of the two diameters i.e.

Maximum transverse diameter + Maximum perpendicular diameter

2

Then the average diameter was calculated in $\mathrm{mm}$ by conversion measurement of an ocular micrometer and a stage micrometer ${ }^{6}$.

iii) Estimation of proportion of parenchyma and stroma: The parenchyma of the thyroid glands consists of the thyroid follicles including follicular epithelial cells, parafollicular cells and the colloid. The stromal part includes connective tissue and vessels.

The proportion of structural components of the thyroid gland was determined with the point counting technique described by Aherne and Dunnill (1966) ${ }^{7}$. Point counting Zeiss-I integrating eyepiece was prepared in a transparent plastic sheet and was placed into the eyepiece. This eyepiece contains a point network of 25 points spaced at $70 \mathrm{~mm}$, arranged within a circle which is regarded as the counting field. Then the counting was done. The position of each point falling on any structural component was recorded for each field. Then the eyepiece was rotated $90^{\circ}$ keeping the field constant. Again the position of the each point was recorded. Thus 50 points were recorded for each field. Five such fields or 250 points were studied on each section. The total number of points fitting each component was summed up and expressed as a percentage of the total number of points fitting the structural component of thyroid glands. This percentage represents the proportion of parenchyma (glandular tissue) and stroma. The data collected from the histological studies were processed and statistical analysis was done by one-way ANOVA test, using the SPSS 11.0 version.

\section{Results}

The number and average diameter of thyroid follicles per square milli meter in different age group is shown in Table II. The proportion of parenchyma and stroma of the thyroid gland in different age group is shown in Table III.

Table II: Number and average diameter of follicles

\begin{tabular}{lcc}
\hline $\begin{array}{l}\text { Group } \\
(\mathrm{n})\end{array}$ & $\begin{array}{c}\text { Number (per sq. mm) } \\
\text { Mean } \pm \text { SD }\end{array}$ & $\begin{array}{c}\text { Diameter (im) } \\
\text { Mean } \pm \text { SD }\end{array}$ \\
\hline A (10) & $23.40 \pm 2.74$ & $171.29 \pm 3.95$ \\
& $(165.75178 .36)$ & $(20.2827 .20)$ \\
B(10) & $30.11 \pm 2.81$ & $210.00 \pm 20.02$ \\
& $(26.1834 .66)$ & $(180.78240 .22)$ \\
C(10) & $21.26 \pm 1.62$ & $170.55 \pm 4.31$ \\
& $(19.5224 .28)$ & $(164.86178 .72)$ \\
\hline A vs B & P value & P value \\
A vs C & $>0.001 * * *$ & $<0.001 * * *$ \\
B vs C & $<0.001 * * *$ & $>0.05 n s$ \\
\hline
\end{tabular}

Figures in parentheses indicate range. Comparison between different age group by One way ANOVA (PostHoc), $\mathrm{ns}=$ not significant, $* * *=$ significant, $\mathrm{n}=$ number of observations 


\section{Article}

Table III: Proportion of parenchyma and stroma

\begin{tabular}{lcc}
\hline $\begin{array}{l}\text { Group } \\
(\mathrm{n})\end{array}$ & $\begin{array}{c}\text { Parenchyma (\%) } \\
\text { Mean } \pm \mathrm{SD}\end{array}$ & $\begin{array}{c}\text { Stroma (\%) } \\
\text { Mean } \pm \mathrm{SD}\end{array}$ \\
\hline $\mathrm{A}(10)$ & $62.02 \pm 1.91$ & $37.96 \pm 1.91$ \\
& $(58.20-64.40)$ & $(35.60-41.80)$ \\
$\mathrm{B}(10)$ & $68.50 \pm 2.55$ & $33.50 \pm 3.31$ \\
& $(63.20-72.80)$ & $(30.20-39.80)$ \\
$\mathrm{C}(10)$ & $62.78 \pm 3.38$ & $37.52 \pm 3.04$ \\
& $(58.8068 .20)$ & $(31.8041 .20)$ \\
\hline & P value & P value \\
\hline A vs B & $<0.001 * * *$ & $<0.01 * *$ \\
A vs C & $>0.50 \mathrm{~ns}$ & $>0.50 \mathrm{~ns}$ \\
B vs C & $<0.001 * * *$ & $<0.01 * *$ \\
\hline
\end{tabular}

Figures in parentheses indicate range. Comparison between different age group by One way ANOVA (PostHoc), ns = not significant, $* * / * * *=$ significant

\section{Discussion}

Jackson $(1931)^{8}$ performed a histomorphometric study of the sections of the thyroid gland of men and found that the follicles increased in length and breadth with age. He found the length as low as $30.6 \pm 0.72 \mathrm{im}$ and as great as $62.7 \pm 1.8 \mu \mathrm{m}$ where he measured follicles of various shapes e.g. angular, round, oval etc. Saadeh and Babikian (1978) ${ }^{9}$ found the thyroid follicular size ranging from 178.4 to $221.5 \mu \mathrm{m}$ (average $198.1 \mu \mathrm{m}$ ) in human. Berkovitz (2005) ${ }^{10}$ stated that the size of the normal follicle is about $0.02-0.9 \mathrm{~mm}$ in diameter. Enayetullah (1996) ${ }^{6}$ found the mean \pm SD follicular number per sq. $\mathrm{mm}$. were $30.44 \pm 3.25$, $24.63 \pm 3.04$ and $33.11 \pm 3.13$ in group $A\left(3^{1 / 2}-20\right.$ years), B (21-40 years) and C (40-78 years) respectively and mean \pm SD follicular percentage were $58.55 \pm 10.72 \%, 63.79 \pm 12.35 \%$ and $63.39 \pm$ $8.29 \%$ in group A, B and C respectively. There was no significant difference between different age group except in number of follicles in group A \& B. Begum et al. (2007) ${ }^{11}$ found the mean \pm SD follicular number per sq. mm. were $30.49 \pm$ $3.82,25.35 \pm 3.52$ and $35.21 \pm 3.11$ in group $\mathrm{A}(0-20$ years), B (21-50 years) and C (>50 years)
Thyroid Follicles and Parenchyma in Bangladeshi People

respectively and later Begum et al. (2008) ${ }^{12}$ stated that the mean \pm SD follicular percentage were $59.58 \pm 13.05 \%, 69.05 \pm 1.50 \%$ and $69.13 \pm 9.29 \%$ in group A, B and C respectively. Sultana et al. (2007) ${ }^{13}$ found the mean \pm SD follicular number per sq. $\mathrm{mm}$. were $30.49 \pm 1.67,24.87 \pm 2.57$ and $33.49 \pm 2.57$ in group A (up to 18 years), B (19-45 years) and $C$ ( $>45$ years) respectively and mean follicular diameter were $198.45 \mu \mathrm{m}, 265.79 \mu \mathrm{m}$ and $203.50 \mu \mathrm{m}$ in group A, B and C respectively. Significant difference was shown in histological values among different age group in the present study unlike the previous studies in Bangladesh. The average values of the present study are more or less consistent with that of the western studies. The morphometric changes in old age can be regarded as reflection of decline in metabolic activities and requirements of the peripheral tissues ${ }^{4}$.

\section{Conclusion}

The number and average diameter of the thyroid follicles and percentage of the parenchyma are found to increase with advancing age during the first 50 years of life and later decrease. Further studies with larger sample and high technical backup and observation in detail e.g. quantitative analysis of glandular epithelium and stroma, volume of colloid, inner follicular space etc. are recommended, both in goiter endemic and nonendemic zones.

\section{Author affiliations}

01. * Abu Sadat Mohammad Nurunnabi, M Phil student, Department of Anatomy, Dhaka Medical College, Dhaka, Bangladesh, Cell Phone: 01712290608, Email: shekhor19@yahoo.com

02. Sabiha Mahbub, Assistant Professor, Department of Anatomy, TMMC, Gazipur, Bangladesh

03. Sunjida Shahriah, Assistant Professor, Department of Anatomy, Chittagong Maa-O-Shishu Hospital \& Medical College, Chittagong, Bangladesh

04. Gul Newaz Begum, Associate Professor, Department of Anatomy, Anwer Khan Modern Medical College, Dhaka, Bangladesh

05. Shamim Ara, Professor and Head, Department of Anatomy, Dhaka Medical College, Dhaka, Bangladesh

*For correspondence

J Bangladesh Soc Physiol. 2009 Dec;4(2): 88-92 


\section{References}

1. Ross MH, Pawlina W. Histology: a text and atlas with correlated cell and molecular biology. $5^{\text {th }}$ ed. Baltimore: Lippincott Williams \& Wilkins; 2006. p.700-4.

2. Junqueira LC, Carneiro J. Basic histology: text and atlas. $11^{\text {th }}$ ed. New York: McGraw-Hill; 2005. p.411-5.

3. Brown RA, Al-Moussa M, Beck JS. Histometry of normal thyroid in man. J. Clin. Pathol. 1986; 39: 475-82.

4. Kumar V, Abbas AK, Fausto N. editors. Robbins and Cotran pathologic basis of disease. $7^{\text {th }}$ ed. New Delhi: Saunders; 2004. p.1164-83.

5. Roberts PF. Variation in the morphometry of the normal human thyroid in growth and ageing. J. Pathol. 1974; 112: 161-8.

6. Enayetullah M. Gross and histomorphological study of the thyroid and parathyroid glands in Bangladeshi people (M.Phil.Thesis). Dhaka: IPGMR, University of Dhaka; 1996.

7. Aherne W, Dunnill MS. Quantitative aspects of placental structure. J Pathol Bacteriol. 1966; 91: 123-39.
8. Jackson JL. The shape and size of human thyroid follicle in health and disease. Anatomical record. 1931; 48: 220-37.

9. Saadeh FA, Babikian LG. A comparative histologic study of thyroid follicular size and epithelium percentage in certain mammals. Anat. Anz. 1978; 143: 96-99.

10. Berkovitz BK. editor. Neck and upper aero-digestive tract. In: Standring S, Ellis H, Heally JC et al. editors. Gray's Anatomy: The anatomical basis of clinical practice. $39^{\text {th }}$ ed. Edinburgh: Elsevier Churchill Livingstone; 2005. p.560-4.

11. Begum M, Shefayetullah KM, Naushaba H, Begum S, Khatun M, Naher S. Histological study of thyroid gland - a postmortem study. Bangladesh J. Anat. 2007 Jan; 5(1): 36-38.

12. Begum M, Shefayetullah KM, Naushaba H, Alam J. Proportion of glandular tissue and stroma of thyroid gland in different age groups - a postmortem study. Sir Salimullah Med. Coll. J. 2008 Jan; 16(1): 11-13.

13. Sultana SZ, Khan MK, Sultana S, Rahman MH, Khalil M, Khalil M. Histomorphometric study of thyroid gland of Bangladeshi people. Mymensingh Med J. 2007 Jan; 16(1): 36-42. 